\title{
The acetylator phenotypes of Saudi Arabian diabetics
}

\author{
DAVID A PRICE EVANS, SHEILA PATERSON, PILAR FRANCISCO, AND \\ GEORGIANA ALVAREZ
}

From the Riyadh Armed Forces Hospital, PO Box 7897, Riyadh 11159, Kingdom of Saudi Arabia.

SUMMARY There is a significant association between the rapid acetylator phenotype and diabetes in European populations. Diabetes is a common problem in Saudi Arabians with some clinical features differentiating it from the disorder in Europeans. A series of 100 Saudi diabetics and 100 Saudi controls has been acetylator phenotyped. The controls showed 33 rapid acetylators (R) and 67 slow acetylators (S), a result closely similar to that previously published for the Saudi population. Overall the diabetics showed $27 \mathrm{R}$ and $73 \mathrm{~S}$ which is not significantly different from the controls. The type I diabetics, however, showed two $\mathrm{R}$ and $22 \mathrm{~S}$ which is not only significantly different from the controls and the type II diabetics, but also the reverse of the association found in European populations.

The idea that one phenotype within a polymorphism might be more prone than the other phenotypes to develop a given disorder was proposed by Alexander ${ }^{1}$ (though at the time the biological significance of genetic polymorphism had not been realised). About 30 years ago this idea was put to the test, and particularly extensive investigations were made of the frequencies of the different $\mathrm{ABO}$ blood group types in duodenal ulcer by Clarke et al. ${ }^{2}$ At the same time some difficulties in the interpretation of the statistical associations became apparent.

Since that time many statistical associations of genetic phenotypes with various disorders have been described. The most striking is the association of

Received for publication 6 June 1985.

HLA-B27 with ankylosing spondylitis ${ }^{3}$ and related arthropathies. Even here there is a mystery in that the immunochemical basis remains obscure.

Relatively little work has been published concerning associations between pharmacogenetic polymorphisms and spontaneous disorders. The available knowledge about the acetylator polymorphism in this regard has recently been surveyed. ${ }^{4}$

An early paper ${ }^{5}$ pointed out that in a series of 28 Finnish diabetics there was an unexpectedly high frequency of rapid acetylators. Omitting this index series an analysis of the six series subsequently published has been made in table 1 . For the UK population three series of diabetics have been

TABLE 1 A test of the association between diabetes and the rapid acetylator phenotype. (Modification by Haldane of the method of Woolf. ${ }^{7}$ )

\begin{tabular}{|c|c|c|c|c|c|c|c|c|c|}
\hline \multirow[t]{3}{*}{ Source of data } & \multicolumn{4}{|c|}{ No of subjects } & \multirow{3}{*}{$\begin{array}{l}\text { Relative } \\
\text { incidence } x\end{array}$} & \multirow{3}{*}{$\log _{y} x$} & \multirow{3}{*}{$\begin{array}{l}\text { Sampling } \\
\text { variance } V\end{array}$} & \multirow{3}{*}{$\begin{array}{l}\text { Weight } \\
I=w\end{array}$} & \multirow{3}{*}{$\begin{array}{l}\text { Significance of } \\
\text { difference from } \\
\text { zero } w y^{2}\end{array}$} \\
\hline & \multicolumn{2}{|c|}{ Diabetics } & \multicolumn{2}{|c|}{ Controls } & & & & & \\
\hline & Slow & Rapid & Slow & Rapid & & & & & \\
\hline Pooled UK data ${ }^{x-10}$ & 126 & 144 & 556 & 375 & 1.6929 & 0.5264 & 0.0192 & $52 \cdot 0143$ & 14.4155 \\
\hline Australian data ${ }^{11}$ & 39 & 77 & 58 & 54 & $2 \cdot 1060$ & 0.7448 & $(0 \cdot() 730$ & $13 \cdot 7077$ & $7 \cdot 6(141$ \\
\hline Spanish data ${ }^{12}$ & 67 & 52 & 90 & 67 & $1 \cdot() 428$ & $0 .(0419$ & 0.0593 & $16 \cdot 8723$ & 0.0296 \\
\hline Italian data ${ }^{13}$ & 87 & 69 & 39 & 16 & 1.9015 & 0.6426 & $0 \cdot 1095$ & $9 \cdot 1347$ & $3 \cdot 7724$ \\
\hline
\end{tabular}

Weighted mean value of $y=Y=\frac{\Sigma w y}{\Sigma w}=\frac{44 \cdot 1696}{91.7291}=0.4815$.

SD of $Y=(\Sigma w)^{-1 / 2}=0 \cdot 1044$.

$95 \%$ fiducial limits $=Y \pm t_{0.025 \cdot 3}(\Sigma w)^{-1 / 2}=+0 \cdot 8138$ and $+0 \cdot 1493$.

Antilog $\mathrm{Y}=\mathrm{X}=1.6185$.

The equivalent $X$ values to the $95 \%$ fiducial limits of $Y$ are 2.2564 and $1 \cdot 1610$.

Significance of difference of $X$ from unity $=\chi_{1}^{2}=\frac{(\Sigma w y)^{2}}{\Sigma w}=21 \cdot 27$.

Homogeneity estimate $=\chi_{N-1}^{2}=\Sigma w y^{2}-\frac{\left(\sum w y\right)^{2}}{\sum w}=4 \cdot 55$. 
pooled, and a large control population has been assembled from various publications as previously described. ${ }^{4}$ There was no heterogeneity between the series (all of which were European in origin) in that they all showed some increase in frequency of rapid acetylators among diabetics as compared with their own control groups. The mean relative incidence is about $1 \cdot 6$.

Diabetes is a common disorder among Saudi Arabians. One notable differentiating clinical feature is the ability of many diabetics to tolerate a grossly raised plasma glucose concentration without symptoms. ${ }^{14}$

The present study was undertaken to see if there was an association between either acetylator phenotype and diabetes in Saudi Arabians, and to see how the result compared with the association known in Europeans.

\section{Methods}

Diabetics studied were inpatients and outpatients of the Riyadh Armed Forces Hospital. All gave informed consent for the acetylator phenotyping test

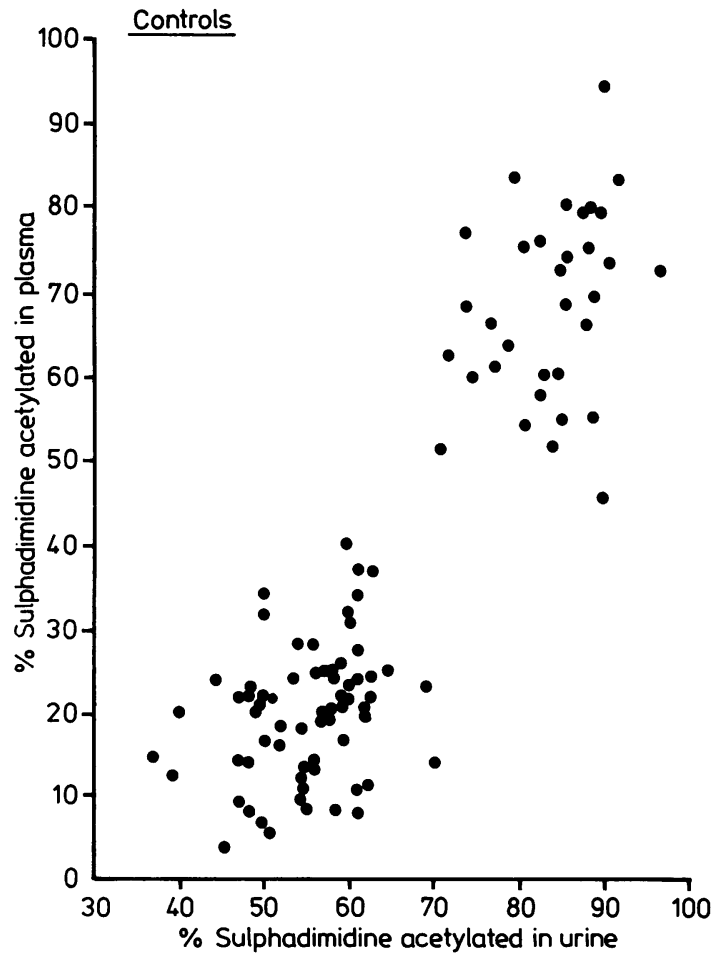

FIG 1 The results of the acetylator phenotyping test in healthy Saudi Arabian controls.

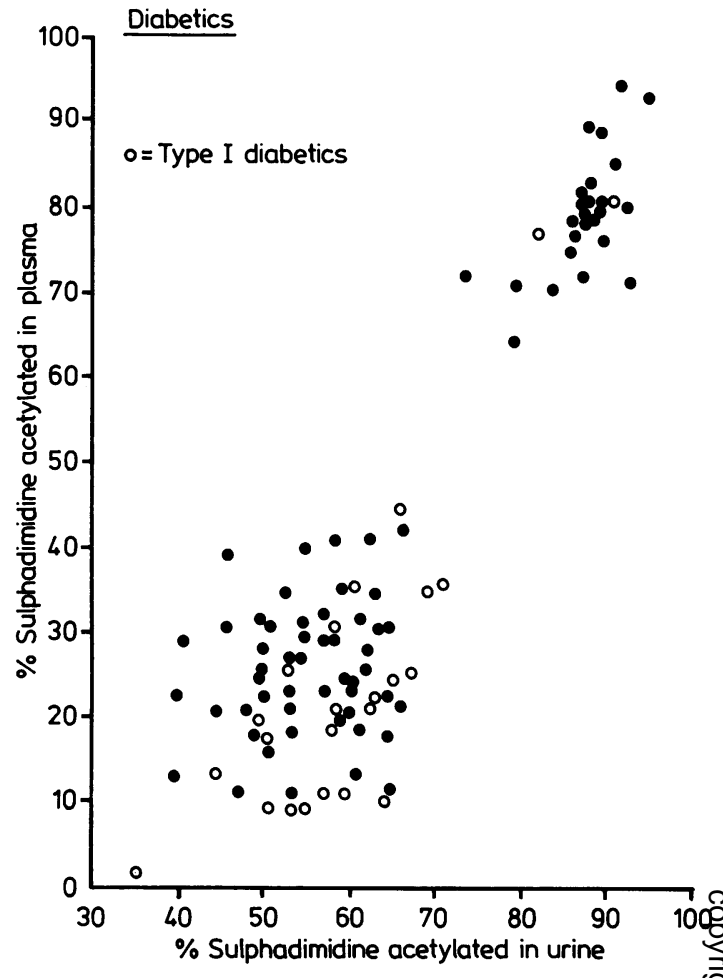

FIG 2 The results of the acetylator phenotyping test in Saudi Arabian diabetic patients.

to be carried out on them. Their diabetic treatment, including diet, was withheld on the morning of the test. Patients were categorised as type I or type II diabetics according to the standard published criteria. ${ }^{15}$ It is sometimes difficult to categorise an individual patient, and in this series the errors, if any, are in one direction, that is, a type I patient may be called type II but not vice versa.

Healthy control subjects were recruited from the Saudi Arabian staff of the hospital, visitors to the hospital, and 'watchers' (a watcher is a healthy person who stays with a seriously ill patient in hospital and tends to his or her needs).

It was ensured that the patients and controls were all unrelated.

The phenotyping procedure was carried out as described in method II of Evans 1969. ${ }^{16}$ A urine sample was obtained from each subject immediately before he or she swallowed the test dose of sulphadimidine. This is referred to below as the 'pre-test' urine. The six hour blood and five to six hour urine following drug ingestion were obtained from all subjects. 
TABLE 2 The distribution of acetylator phenotypes in Saudi diabetics and controls.

\begin{tabular}{lccl}
\hline $\begin{array}{l}\text { Acetylator } \\
\text { phenotype }\end{array}$ & Controls & $\begin{array}{l}\text { Type I } \\
\text { diabetics }\end{array}$ & $\begin{array}{l}\text { Type II } \\
\text { diahetics }\end{array}$ \\
\hline Rapid & 33 & 2 & 25 \\
Slow & 67 & 22 & 51 \\
Total & 100 & 24 & 76 \\
\hline
\end{tabular}

The analyses were carried out by an adaptation of the Bratton-Marshall procedure. ${ }^{17}$

\section{Results}

Several pre-test urines showed the presence of chemicals reacting in the Bratton-Marshall reaction. Presumably these were traces of previously ingested drugs. In no instance was the amount sufficient to interfere with the phenotyping procedure. The results of the phenotyping tests are shown in figs 1 and 2 .

The dividing line between the phenotypes for both diabetics and controls has been taken to be $45 \%$ sulphadimidine acetylated in the plasma. The distribution of phenotypes is shown in table 2 , and the distribution of ages, weights, and heights in tables 3,4 , and 5 . In these tables it will be seen that the type I diabetics were younger than the type II diabetics.

The frequency of the allele controlling slow acetylation in the healthy control subjects is $0 \cdot 8185$.

The 'relative incidence' has been calculated for all the diabetics versus the controls in the same way as in table 1 so that an association between diabetes

TABLE 3 The distribution of ages (years) in Saudi diabetic and control subjects.

\begin{tabular}{|c|c|c|c|c|c|}
\hline \multirow[t]{2}{*}{ Sex } & \multirow{2}{*}{$\begin{array}{l}\text { Acetylator } \\
\text { phenotype }\end{array}$} & \multirow[t]{2}{*}{ Parameter } & \multicolumn{3}{|c|}{ Category of subject } \\
\hline & & & Control & $\begin{array}{l}\text { Type I } \\
\text { diabetic }\end{array}$ & $\begin{array}{l}\text { Type II } \\
\text { diabetic }\end{array}$ \\
\hline \multirow[t]{3}{*}{ Male } & \multirow[t]{3}{*}{ Slow } & $\mathrm{N}$ & 30 & 14 & 31 \\
\hline & & $\mathbf{M}$ & 31.967 & $22 \cdot 429$ & $47 \cdot 774$ \\
\hline & & $\mathrm{SD}$ & $9 \cdot 260$ & $7 \cdot 208$ & $12 \cdot 766$ \\
\hline \multirow[t]{3}{*}{ Female } & \multirow[t]{3}{*}{ Slow } & $\mathrm{N}$ & 37 & 8 & 20 \\
\hline & & $\mathbf{M}$ & $26 \cdot 757$ & $22 \cdot 5(x)$ & $5(0 \cdot 450$ \\
\hline & & SD & 9.731 & $8 \cdot 036$ & 10.575 \\
\hline \multirow[t]{3}{*}{ Male } & \multirow[t]{3}{*}{ Rapid } & $\mathrm{N}$ & 11 & 1 & 18 \\
\hline & & $\mathbf{M}$ & $31 \cdot 182$ & 27 & $52 \cdot 111$ \\
\hline & & $\mathrm{SD}$ & $10 \cdot 852$ & -- & 9.964 \\
\hline \multirow[t]{3}{*}{ Female } & \multirow[t]{3}{*}{ Rapid } & $\mathbf{N}$ & 22 & 1 & 7 \\
\hline & & $\mathbf{M}$ & $27 \cdot 682$ & 14 & $46 \cdot 286$ \\
\hline & & SD & 9.727 & - & $11 \cdot 615$ \\
\hline
\end{tabular}

$\mathrm{N}=$ number

$\mathbf{M}=$ mean.

$\mathrm{SD}=$ standard deviation.
TABLE 4 The distribution of body weights $(\mathrm{kg})$ in Saudi diabetic and control subjects.

\begin{tabular}{|c|c|c|c|c|c|}
\hline \multirow[t]{2}{*}{ Sex } & \multirow{2}{*}{$\begin{array}{l}\text { Acetylator } \\
\text { phenotype }\end{array}$} & \multirow[t]{2}{*}{ Parameter } & \multicolumn{3}{|c|}{ Category of subject } \\
\hline & & & Control & $\begin{array}{l}\text { Type I } \\
\text { diaberic }\end{array}$ & $\begin{array}{l}\text { Type II } \\
\text { diabetic }\end{array}$ \\
\hline \multirow[t]{3}{*}{ Malc } & \multirow[t]{3}{*}{ Slow } & $\mathrm{N}$ & 27 & 7 & 31 \\
\hline & & $\mathbf{M}$ & 67.778 & $63 \cdot 429$ & $71 \cdot 32.3$ \\
\hline & & SD & $10 \cdot 8.50$ & $9 \cdot 880$ & $11 \cdot 870$ \\
\hline \multirow[t]{3}{*}{ Female } & \multirow[t]{3}{*}{ Slow } & $\mathrm{N}$ & 28 & 4 & 20 \\
\hline & & $\mathbf{M}$ & $65 \cdot(1000$ & $65 \cdot 5()(1)$ & $64 \cdot 400$ \\
\hline & & SD & $12 \cdot 1137$ & $13 \cdot 077$ & $11 \cdot 176$ \\
\hline \multirow[t]{3}{*}{ Male } & \multirow[t]{3}{*}{ Rapid } & $\mathrm{N}$ & 8 & 1 & 18 \\
\hline & & M & 76.625 & 50 & $70 \cdot 500$ \\
\hline & & SD & 10.555 & - & 12.590 \\
\hline \multirow[t]{3}{*}{ Female } & \multirow[t]{3}{*}{ Rapid } & $\mathrm{N}$ & 15 & - & 7 \\
\hline & & $M$ & 65.733 & - & $6.5 \cdot 429$ \\
\hline & & SD & 6.724 & - & 10.277 \\
\hline
\end{tabular}

Persons aged 21 years and less have been omitted.

$\mathrm{N}=$ number.

$M=$ mean.

$\mathrm{SD}=$ standard deviation

TABLE 5 The distribution of heights $(\mathrm{cm})$ in Saudi diabetic and control subjects.

\begin{tabular}{|c|c|c|c|c|c|}
\hline \multirow[t]{2}{*}{ Sex } & \multirow{2}{*}{$\begin{array}{l}\text { Acetylator } \\
\text { phenotype }\end{array}$} & \multirow[t]{2}{*}{ Parameter } & \multicolumn{3}{|c|}{ Category of subject } \\
\hline & & & Control & $\begin{array}{l}\text { Type I } \\
\text { diabetic }\end{array}$ & $\begin{array}{l}\text { Type II } \\
\text { diabetic }\end{array}$ \\
\hline \multirow[t]{3}{*}{ Male } & \multirow[t]{3}{*}{ Slow } & $\mathrm{N}$ & 27 & 7 & 31 \\
\hline & & $\mathbf{M}$ & $163 \cdot 556$ & $166 \cdot 143$ & $163 \cdot 258$ \\
\hline & & SD & $10 \cdot 882$ & 7.777 & $6 \cdot 392$ \\
\hline \multirow[t]{3}{*}{ Female } & \multirow[t]{3}{*}{ Slow } & $\mathrm{N}$ & 28 & 4 & 20 \\
\hline & & 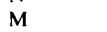 & $148 \cdot 821$ & $153 \cdot 5(x)$ & $153 \cdot 6(x)$ \\
\hline & & SD & $10 \cdot 278$ & $3 \cdot 697$ & $6 \cdot(1) 30$ \\
\hline \multirow[t]{3}{*}{ Male } & \multirow[t]{3}{*}{ Rapid } & $\mathrm{N}$ & 8 & 1 & 18 \\
\hline & & M & $162 \cdot 50(0)$ & 169 & $166 \cdot 00(0)$ \\
\hline & & $\mathrm{SD}$ & $12 \cdot 177$ & - & 9.622 \\
\hline \multirow[t]{3}{*}{ Female } & \multirow[t]{3}{*}{ Rapid } & $\mathrm{N}$ & 15 & - & 7 \\
\hline & & $\mathrm{M}$ & $147 \cdot 133$ & - & $154 \cdot 429$ \\
\hline & & SD & $8 \cdot 814$ & - & $5 \cdot 255$ \\
\hline
\end{tabular}

Persons aged 21 years and less have been omitted. $\mathrm{N}=$ number.

$\mathbf{M}=$ mean.

$\mathrm{SD}=$ standard deviation

and rapid acetylation would give a value $>1$. The value obtained was $0.7539\left(\log _{\mathrm{e}}=-0.2825\right)$ which is 7.3 SD below the mean of the series in table 1 .

There was no significant difference in the frequencies of the phenotypes when all the diabetics were compared with all the controls $\left(\chi_{1}^{2}=0 \cdot 857\right)$. There was, however, a significant difference in phenotype frequencies when type I and type II diabetics were compared $\left(\chi_{1}^{2}=5.58, \mathrm{p}<0.02\right)$. The phenotype frequencies in type II diabetics were closely similar to those in the controls.

\section{Discussion}

Figs 1 and 2 show that there is no interference by diabetes in the phenotyping test procedure. 
The allele frequency in the controls is similar to that previously described in surveys of Saudi Arabians $^{18}$ and other adjacent Middle Eastern populations. ${ }^{19}$ This is of interest because the present subjects were Saudi nationals mainly from the central and southern regions, whereas the previous surveys had been conducted from the more heterogeneous populations in the western region.

In the population of Saudi diabetics there is a significant association between slow acetylation and type I diabetes.

It might be postulated that the phenotyping results in type I diabetics might have been affected in some way by the fact that they were on insulin treatment. This idea has been disproved by comparing the phenotype frequencies in type II diabetics who were and who were not receiving insulin.

In 34 in the former category there were 10 rapid acetylators, and in 42 in the latter category there were 15 rapid acetylators $\left(\chi_{i}^{2}=0 \cdot 34\right)$.

The analysis of diabetics in table 1 pooled both types of diabetes together. This was done because it is not possible consistently to disentangle the two types from the published series. An attempt to show the breakdown is shown in table 6 , where it is clear that there is a very high frequency of rapid acetylators in European type I diabetics.

The present preliminary series suggests that as far as the association with the acetylator polymorphism is concerned, type I Saudi diabetics are quite different from type I European diabetics. Further series will be required to confirm or refute the present finding.

There is one appealing feature in studying associations of pharmacogenetic polymorphisms with spontaneous disorders. This is because the biochemical

TABLE 6 Details of the acetylator phenotypes in different categories of diabetics.

\begin{tabular}{|c|c|c|}
\hline Reference & \multicolumn{2}{|l|}{ Denuils of results } \\
\hline \multirow[t]{3}{*}{5} & \multirow{3}{*}{\multicolumn{2}{|c|}{$\begin{array}{l}28 \text { diabetics, } 25 \text { on insulin } \\
\text { Overall } 13 \mathrm{R} 15 \mathrm{~S} \\
7 \text { out of } 9 \text { patients aged less than } 16 \\
\text { years were rapid acetylators }\end{array}$}} \\
\hline & & \\
\hline & & \\
\hline 8 & Type I & 27 R S S \\
\hline \multirow[t]{2}{*}{9} & Juvenile onset & $27 \mathrm{R} 22 \mathrm{~S}$ \\
\hline & Maturity onset & $42 \mathrm{R} 39 \mathrm{~S}$ \\
\hline \multirow[t]{2}{*}{10} & 'Many juvenile onset' & $19 \mathrm{R} 19 \mathrm{~S}$ \\
\hline & Maturity onset & $29 \mathrm{R}$ Is \\
\hline \multirow[t]{2}{*}{11} & Type I & $35 \mathrm{R} 12 \mathrm{~S}$ \\
\hline & Type II & $42 \mathrm{R} 27 \mathrm{~S}$ \\
\hline \multirow{2}{*}{12} & Juvenile onset & $15 \mathrm{R} 17 \mathrm{~S}$ \\
\hline & Adult onsel & $37 \mathrm{R} 50 \mathrm{~S}$ \\
\hline \multirow{2}{*}{13} & Type I & $32 \mathrm{R} 29 \mathrm{~S}$ \\
\hline & Туре 11 & $37 \mathrm{R}$ 58. \\
\hline
\end{tabular}

$\mathrm{R}=$ rapid acetylator

$\mathrm{S}=$ slow acetylator. bases of the polymorphisms are known. To acetylate the test drug in the acetylator polymorphism, acetyl groups are transferred from acetyl $\mathrm{CoA}$ by the action of the polymorphic $\mathrm{N}$-acetyl transferase. ${ }^{2021}$ It is implicit in the phenotyping test that there is an abundant supply of acetyl CoA available.

Disturbances related to this area of metabolism are known in experimental diabetes, for example, the liver concentration and production of acetate is known to be increased in alloxan treated rats and sheep. 222.3

The interpretation of the associations of the acetylator phenotypes with diabetes is speculative because the natural substrates for the polymorphic $\mathrm{N}$-acetyl transferase are unknown. A clue to a possibly relevant class of natural substrates is provided by the recent finding that the amino methyl uracil which is an important metabolite of caffeine is polymorphically acetylated. ${ }^{24-27}$ There is evidence that this compound is found in the urines of caffeine-free subjects. ${ }^{28}$

Provided that the present finding about type I Saudi diabetes is confirmed, then an hypothesis could be entertained as follows: that a toxic natural substrate which is a factor in precipitating type I diabetes is relatively ineffectively detoxicated by slow acetylators. This hypothesis would not however fit the facts as far as European diabetics are concerned, and so in them some other mechanismo would have to be invoked to explain their association with the rapid acetylator phenotype.

We thank the Research and Ethical Committee of the Riyadh Armed Forces Hospital (Chairman Dr Mohamed Al Fagih) and the Special Development Fund of the Riyadh Armed Forces Hospital (Chairman Dr Mohamed Abomelha) for funding the project, Dr R A Bacchus, Director of the Central Laboratory, Riyadh Armed Forces Hospital for analytical facilities, and Miss Margaret A Johnston for preparing the manuscript.

\footnotetext{
References

1 Alexander W. An inquiry into the distribution of the blood groups in patients suffering from malignant disease. $\mathrm{Br} J$ Exp Pathol 1921:2:66-9.

2 Clarke CA, Edwards JW, Haddock DRW, Howel-Evans A, McConnell RB, Sheppard PM. ABO blood groups and secretor character in duodenal ulcer. Population and sibship studies. $\mathrm{Br}$ Med J 1956;2:725-31.

${ }^{3}$ Dick HM. Sturrock RD. Dick WC, Buchannan WW. Inheritance of ankylosing spondylitis and HLA antigen W27. Lancet 1974:ii:24-5.

${ }^{4}$ Evans DAP. Survey of the human acetylator polymorphism in spontaneous disorders. J Med Genet 1984;21:243-53.

'Mattila MJ. Tiitinen $\mathrm{H}$. The rate of isoniazid inactivation in Finnish diabetic and non-diabetic patients. Ann Med Exp Biol Fenn 1967:45:423-7.
} 
${ }^{6}$ Haldane JBS. The estimation and significance of the logarithm of a ratio of frequence. Ann Hum Genet 1955-56;20:309-11.

${ }^{7}$ Woolf $B$. On estimating the relation between blood group and disease. Ann Hum Genet 1954-55;19:251-3.

${ }^{8}$ Bodansky HJ, Drury PL, Cudworth AG, Evans DAP. Acetylator phenotypes and type I (insulin-dependent) diabetics with microvascular disease. Diabetes 1981;30:907-10.

${ }^{9}$ McLaren EH, Burden AC. Moorhead PJ. Acetylator phenotype in diabetic neuropathy. $\mathrm{Br}$ Med J 1977;ii:291-3.

10 Burrows AW, Hockaday TDR, Mann JI, Taylor JG. Diabetic dimorphism according to acetylator status. $\mathrm{Br} \mathrm{Med} J$ 1978;i:20810.

1 Shenfield GM, McCann VJ, Tjokresetio R. Acetylator status and diabetic neuropathy. Diabetologia 1982;22:441-4.

12 Ladero JM, Arrojo A, deSalamanca RE, Gomez M. Cano F, Alfonso M. Hepatic acetylator phenotype in diabetes mellitus. Ann Clin Res 1982;14:187-9.

13 Pontiroli AE, Mosca A, dePasqua A, Alcini D, Pozza G. The fast acetylator phenotype in diabetes mellitus: abnormal prevalence and association with the $\mathrm{ABO}$ blood groups. Diabetologia 1984;27:235-7.

14 Kingston M, Skoog WC. Diabetes in Saudi Arabia. Saudi Med J (in press).

15 National Diabetes Data Group. Classification and diagnosis of diabetes mellitus and other categories of glucose intolerance. Diabetes 1979;28:1039-57.

16 Evans DAP. An improved and simplified method of detecting the acetylator phenotype. J Med Genet 1969;6:405-7.

17 Varley H. Practical clinical biochemistry. 3rd ed. London: Heinemann, 1963:632-6.

${ }^{18}$ Islam SI. Polymorphic acetylation of sulphamethazine in rural Bedouin and urban dwellers in Saudi Arabia. Xenobiotica 1982;12:323-8.

${ }^{19}$ Karim AKMB, Elfellah MS, Evans DAP. Human acetylator polymorphism: estimate of allele frequency in Libya and details of global distribution. J Med Genet 1981;18:325-30.
20) Evans DAP, White TA. Human acetylation polymorphism. $J$ Lab Clin Med 1964;63:394-403.

21 Jenne JW. Partial purification and properties of the isoniazid transacetylase in human liver. Its relationship to the acetylation of p-amino salicylic acid. J Clin Invest 1965;44:1992-2002.

22 Knowles SE, Jarrett IG, Filsell OH, Ballard FJ. Production and utilisation of acetate in mammals. Biochem $J$ 1974:142:401-11.

${ }^{23}$ Senfert CD, Graf M, Janson G, Kuhn A, Soling HD. Formation of free acetate by isolated perfused livers from normal, starved and diabetic rats. Biochem Biophys Res Commun 1974:57:9018.

${ }^{24}$ Tang BK, Grant DM, Kalow W. Isolation and identification of 5-acetylamino-6-formylamino-3-methyluracil as a major metabolite of caffeine in man. Drug Metab Dispos 1983;11:21820.

25 Grant DM, Tang BK, Kalow W. Polymorphic N-acetylation of a caffeine metabolite. Clin Pharmacol Ther 1983:33:355-9.

${ }^{26}$ Branfman AR, McComish MF, Bruni RJ, Callahan MM, Robertson R, Yesair DW. Characterisation of diaminouracil metabolites of caffeine in human urine. Drug Metab Dispos 1983;11:206-10.

27 Callahan MM, Robertson RS, Branfman AR, McComish MF, Yesair DW. Comparison of caffeine metabolism in three non-smoking populations after oral administration of radiolabeled caffeine. Drug Metab Dispos 1983;11:211-7.

${ }^{28}$ Fink W, Adams WS, Pfleiderer W. A new urinary pyrimidine 5 acetyl amino-6-amino-3-methyl uracil. $J$ Biol Chem 1961;239:4250-6

Correspondence and requests for reprints to Dr D A Price Evans, Department of Medicine, Riyadh Armed Forces Hospital, PO Box 7897, Riyadh 11159, Kingdom of Saudi Arabia. 